\title{
Acta Didactica Napocensia
}

Volume 12, Number 2, 2019 - DOI: 10.24193/adn.12.2.15

\section{EFFECTIVENESS OF APPLYING THE LEARNING TOGETHER METHOD AT DifFERENT INTERVALS IN TEACHING SCIENCE} Fulya ZORLU, Fatih SEZEK

\begin{abstract}
The aim of this study was to examine effectiveness of applying learning together (LT) method at different intervals on improvement of middle school students' academic success and science process skills. The sample of study was cconsist of 117 sixth and seventh grade students in two puplic middle schools. In this study, the "Solomon Experimental Design" was used. In the first year of the application was conducted with sixth grade students, and in the second year, a year later, the same students who graduated to the seventh grade and an additional seventh grade class who had not participated the year before were included in the study. The experimental groups were applied the LT method and control groups were applied the existing method which the middle school science curriculum followed in Turkey was taught. As data collection tools, Preliminary Information Tests, Science Process Skills Tests and Academic Achievement Tests were used. According to the findings, the Solomon Experimental Design, applied twice different intervals in the same group of students, internal and external validity of the research was increased. In conclusion, it was found that the two-time application of the LT in teaching a subject to the same students group was more effective than the one-time.
\end{abstract}

Key words: learning together method, middle science education, science process skills, Solomon experimental design

\section{Introduction}

In the curriculum of science course in Turkey, "Knowledge", "Skill", "Affective" and "ScienceTechnology-Society-Environment" elements are included. With these, individuals are required to earn some qualifications. "Knowledge" learning area; Life, matter, different kinds of energy, concepts of motion and force, scientific information about the world and the universe. One of these areas of the knowledge is the sub-field "Substance and Change"; The nature of the substance, the characteristics of the substance and the changes that occur in the substance (MEB, 2013). In the field of "Skill" learning, life skills as well as of science process skills is included to attainment. Because; It can be contributed by bringing science process skills to the cultivation of a genealogy that learns and produces knowledge in a true sense and is literate (Zorlu, Zorlu, Sezek and Akkuş, 2014). In this context, the subfield of "Science Process Skills"; Including observing, measuring, classifying, recording data, constructing hypotheses, using and modeling data, changing and controlling variables, experimenting (MEB, 2013).

The aim in science courses is to gain science process skills as well as concepts of core knowledge for students. Science process skills (SPS) are mostly examined in two groups. Of them, basic skills can be learned from preschool and integrated skills can be learned from middle school (Ergin, Şahin-Pekmez, and Öngel-Erdal, 2005). According to Zorlu et al. (2014), helping students acquire science process skills is very important to raise a generation who learns and teaches in real terms and who are science literate. SPS help acquire and use knowledge (Mei, Kaling, Xinyi, Sing, and Khoon, 2007). To achieve science education's objectives by enabling students to learn abilities and habits for handling information with a scientific perspective, new methods and techniques have been used in science classes (Daşdemir and Doymuş, 2012; Köseoğlu and Kavak, 2001).

Researches are being carried out on Cooperative Learning Model in Turkey. It has been emphasized that in the meta-analysis studies that have been carried out in our country until now, the effects of conceptual change have been higher in the large working groups of this model (Sarıgöz, 2017; Şen and

Cite as: Fulya Zorlu, F. \& Sezek, F. (2019). Effectiveness of the Learning Together Method at Different Intervals in Teaching Science. Acta Didactica Napocensia, 12(2), 195-208, - DOI: 10.24193/adn.12.2.15. 
Y1lmaz, 2013; Tuncer and Dikmen, 2017). In addition, it was stated that the lowest effect size was in the field of chemistry education, the success tests developed by the researcher were used and the applications concentrated in short time periods such as five-six weeks were included in the analysis of the samples according to the study subjects (Karakuş and Öztürk, 2016). In applications, there are factors such as having conceptual misconceptions about the model, mixing with model group work or cluster studies, and trying to increase the theoretical infrastructure and academic studies accumulation of the models day by day. In this context, studies on Cooperative Learning Models, which are constantly included in curriculum in our country and recommended for their applications, continue.

\subsection{Cooperative Learning Model}

Cooperative Learning Model is one of the contemporary teaching models used for that aim. It is actually a pedagogic model which brings the student actively in learning environment and making them convey the content to their peers through face-to-face interaction (Apugliese and Lewis, 2017; Avc1, 2002; Doymuş and Koç, 2012). Cooperative Learning Model focuses on raising awareness of individuals in matters which they need to possess at every stage of their lives like taking responsibility, reaching information, investigating the unknown and never giving up at young ages and provides benefits to teachers and educators in a broad perspective (Johnson, Johnson, and Holubec, 1994). According to Sharan (2015) is concerned, when its contributions are taken into consideration, it has the potential to be the primary format used by teachers as it converts schooling from being content-oriented to process-oriented.

Positive affiliation, face-to-face interaction, individual evaluability and personal responsibility, interpersonal and small group skills, group process evaluation principles distinguishes the Cooperative Learning Model from other learning models (Johnson and Johnson, 1992). It should be guided to work together each student and be taught that they can be reached by common effort in heterogeneous groups. This awareness is achieved through the establishment of a positive affiliation. Thus, it is the responsibility of the individual and the group to be accountable. Throughout the process, a face-to-face work-and-support interaction environment is created to produce a product. With this interaction, the effectiveness of the group process is assessed by trying to gain the necessary interpersonal and small group skills (Johnson, Johnson and Holubec, 1994).

\subsection{Learning Together Method (LT)}

In this model, students use their abilities and learn cooperatively in small heterogeneous groups in pursuit of a common objective (Açıkgöz, 1992; Johnson and Johnson, 1986; Slavin, 2013). Given the contributions of this model, it changes learning from outcome-content-oriented situations to processoriented (Sharan, 2015). The most commonly known method of cooperative learning is the Learning Together (LT) model. LT has become prominent with its properties of having a group goal, sharing opinions and materials, division of labor and group reward (Bayrakçeken, Doymuş, and Doğan, 2011).

In line with the determined instructional objective, the size of the group is specified in Learning Together Method (LT) and students are divided into heterogeneous groups to explore study and learn together. Thus one of the objectives of education, individual's joining society as a social being would be met in the best possible way and relations, consciousness of living and feelings like devotion to nation and motherland of students with different ethnicities, genders and mentality would be maximized (Bayrakçeken, Doymuş, and Doğan, 2013). Within this period principles like positive dependence, face-to-face supportive interaction, group skills, individual responsibility and assessment of group process are taken into consideration (Johnson and Johnson, 1999). At the end of the cooperative process during which every student does their share groups jointly exhibit the products of their cooperative works. As the group product is constituted as a result of a joint effort, contributions of group members to the product cannot be determined (Wheeler and Ryan, 1973). Students actively share the responsibility with their peers and teachers by actively participating assessment phase.

\subsection{The Aim of Study}

Literature indicated that the cooperative learning model made contributions to students' academic success, attitudes towards science classes, social abilities and science process skills (Bozdoğan, Taşdemir, and Demirbaş, 2006; Doymuş, 2008; Ebrahim, 2012; Karakoyun, 2010; Sanc1 and Kılıç 
2011). There is a problem. Considering the levels of the students, especially studying in primary or middle school, it has been thought that they need time to get used to the LT method and that the efficiency of LT cannot be presented completely after only applying the method once. Therefore, it could be impossible to observe the efficiency of LT completely by applying it only once. Furthermore, it allows comparisons to be made among groups to ensure internal and external validity of the applying which are performed using the Solomon research design and to make a wide range of targetoriented comments (Solomon and Lessac, 1968). This study was aimed to examine effects of applying learning together method at different intervals on improvement of middle school sixth and seventh grade students' academic success and science process skills in teaching science. Answers were sought to the following research questions within the scope of this aim.

\subsection{Research Question}

Is there an effectiveness of applying the learning together method at different intervals on improvement of middle school sixth and seventh grade students' academic success and their science process skills in science classes?

\section{Method}

Among the experimental designs, the most powerful one that keeps internal and external validity intact is the Solomon experimental design. This study was used the Solomon experimental design (Figure 1).

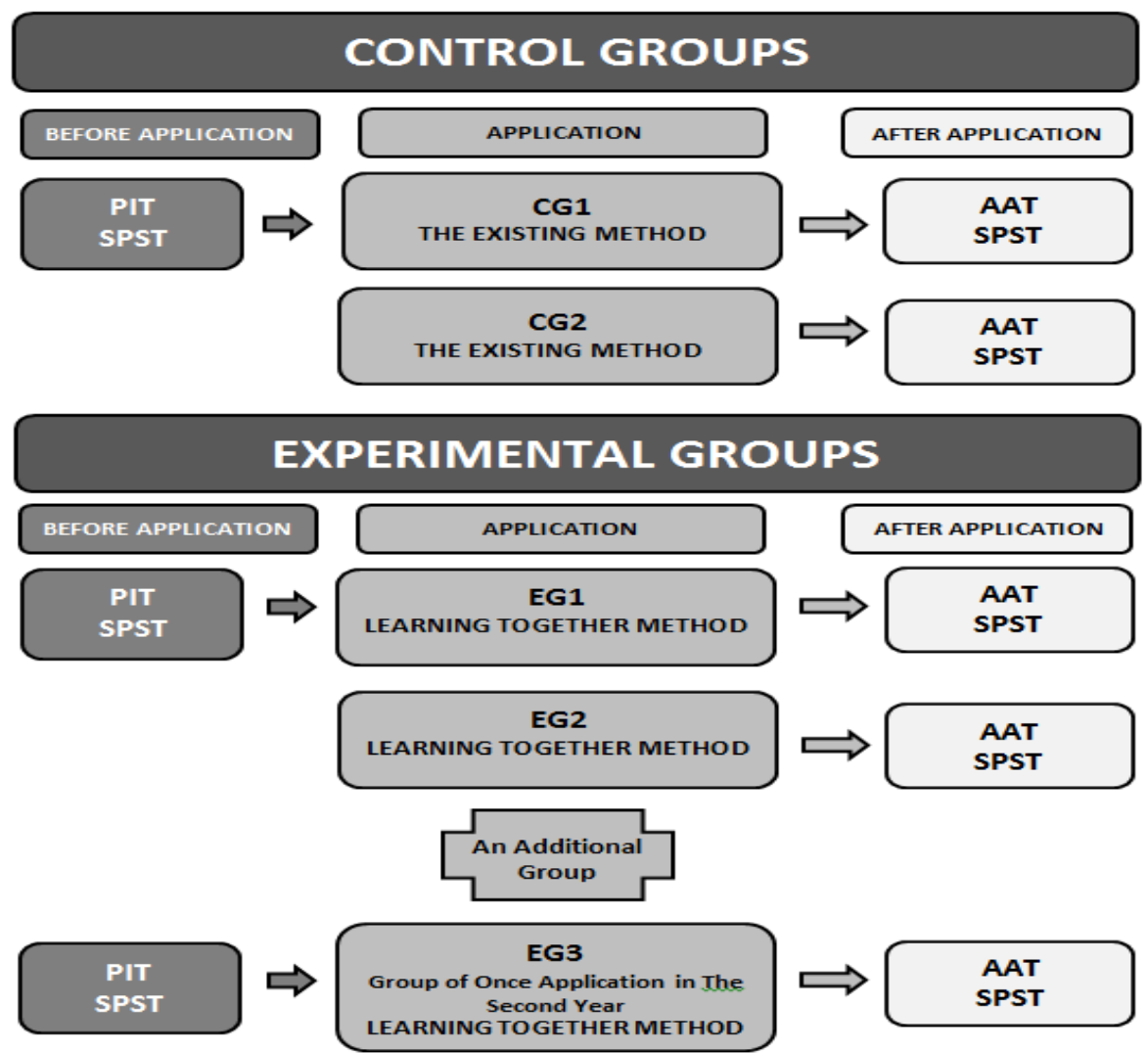

Figure 1. The research experimental designs

In Figure 1, Learning Together Method (LT) was comprised applying of the sixth grade in the first year and of the seventh grade in the second year. This study was performed applying in four sixth grade classes in the first year because of using the Solomon four groups experimental design. The LT and the existing method offered by the Ministry of National Education were applied to the experimental and control groups, respectively. In the second year, this study was applied exactly the same teaching methods which had been applied the previous year to the same experimental group. 
This way, it ensured that students learn similar units of the same learning environment by using the same method over two years. To observe the differences between the students who had experienced the LT method once and those who experienced it twice, the researcher added an additional group to the seventh grade participants who were experiencing the method for the first time. Thus, this study had a experimental design comprising two control and three experimental groups.

\subsection{Participants}

Sample of research was determined via simple random sampling from among the sixth and seventh grade students of two state middle schools under Ministry of National Education. Among state middle schools in Turkey, two middle schools were selected by using simple random sampling. The two middle schools were selected because there aren't number of classrooms required for Solomon experimental design in the one middle school. The middle school to form experimental groups was selected by using simple random sampling and the other school is used to form control groups. Additionally, it is in order to prevent the interaction of students among experimental and control groups. Two experimental groups were randomly selected for the first year. In the second year, a new additional experimental group was added to these two classes. Control groups were randomly selected two classes from the other school. In the second year, the study was continued with the same control groups. Participating students were sixth and seventh grade in 11-13 age range. First year, there were 34 students (15 Female and 19 Male) in control groups, and 53 students (20 Female and 33 Male) in experimental groups. Second year, there were 42 students (17 Female and 25 Male) in control groups, and 80 students (33 Female and 47 Male) in experimental groups.

\section{Curriculum Information about the Units}

The units were performed applications according to the curriculum of MEB. In the first year, unit "Matter and Heat" was applied to sixth grade students in a twelve-hour class. This unit comprised "Particulate Structure of Matter and Heat", "Heat Transmission" and "Heat Insulation" subtopics. In the second year, this study applied unit "Structure and Properties of Matter" to seventh grade students in a twenty four-hour class. This unit comprised "Elements and Symbols", "Structure of The Atom", "Compounds and Formulas", "Electron Configuration and Chemical Properties", "Chemical Bond", "Mixtures" subtopics.

\section{Applications in Experimental and Control Groups}

First year one of the experimental groups is randomly selected (EG1) before starting LT applications and they are subjected to a prior knowledge test on sciences. Other experimental group (EG2) didn't take the prior knowledge test. Depending on their prior knowledge levels on sciences (in accordance with PIT for EG1, and their success in science lessons for EG2) researchers and teachers jointly created cooperative heterogeneous groups of four-five students (According to their success in the lessons, heterogeneous groups were formed by choosing students from all levels. Additionally, relations with peers and balanced gender distributions were also taken into consideration). It is explained them that the topic of "Matter and Heat" is divided into three sub-topics and which topic will be studied which week and duration of class. All students are asked to make research on topics and come back to classroom. Topics are discussed together with students, teachers and researchers. Before discussing the topic, teachers and researchers checked whether the design of classroom is suitable or not. They also attended to groups during the discussion and interfered in case there seems to be a trouble. When students' progress was getting slower, they motivated the students and explained the none-understandable points. When students completed their tasks, they determined the groups to make the presentation by lot. Students made researches on the topics to be discussed before coming to school and prepared some documents and materials. They arranged the layout of classroom in compliance with the studies of cooperative groups announced at the beginning of application. Then they tried to learn the topic along with other members of their groups. They asked for the help of teachers and researchers when needed and tried to perform their tasks. The group to make the presentation is determined by lot in accordance with course hours. Lacking parts are determined during presentation and they are completed via question and answer method. The topic "Structure and Properties of Matter" is discussed the same way in second year. 
Learning in control groups was conducted by taking science curriculum specified by the Ministry of Education in Turkey into consideration. While teachers were lecturing, researchers attended the classes as guests. In the control group, the teacher was asking the students questions about the news in the media or the current situation in their environmental, with respect to the subject. After their attention, he taught by using PowerPoint. The presentations included information, statements, figures and basic concepts on the subject. At the end of his presentation, he randomly selected one or two students in order to summarize the topic. The teacher immediately corrected student's misrepresentations or misconceptions, and also completed the missing information of the students.

\subsection{Data Collection Tools}

Preliminary Information Tests $\left(6^{\text {th }}\right.$ G-PIT and $7^{\text {th }}$ G-PIT $)$ : To observe the sixth and seventh grade students' prior knowledge covering lessons which were taught up to that lesson in science class, the researcher obtained tests from the Scientific and Technological Research Council of Turkey (TUBITAK) Project number $110 \mathrm{~K} 252$. This study determined reliabilities to be 0.77 for $6^{\text {th }} \mathrm{G}$-PIT and 0.63 for $7^{\text {th }}$ G-PIT, respectively. Tests included 25 multiple choice questions, and the students got 4 points for each correct answer. The test was worth 100 points in total.

Science Process Tests $\left(6^{\text {th }}\right.$ G-SPST and $7^{\text {th }}$ G-SPST): The science process skills test used for the sixth grade students $\left(6^{\text {th }} \mathrm{G}-\mathrm{SPST}\right)$ was developed by Tobin and Copie (1981). This test was translated into Turkish and statistically analyzed by Arslan (1995) and comprised 46 multiple choice items with 4 choices. In this test, there are questions to measure basic, causal and experimental science process skills. Six categories of this test are: "Logical Thinking" (13 multiple choice items, 5 multiple choice items are two-stage), "Predicting" (6 multiple choice items), "Questioning" (6 multiple choice items), "Researching" (10 multiple choice items), "Communicating" (13 multiple choice items), "Planning and Producing" (5 multiple choice items). Arslan (1995) performed reliability studies of this test with 250 students and found the alpha reliability coefficient to be 0.73 (Erdoğan, 2010). In this test, the students got 1 point for each correct answer. The test was worth 46 points in total.

This study used science process skills test for seventh grade students (7thG-SPST) was originally developed by Smith and Welliver and adapted to Turkish by Başdağ (2006). This test measuring a total of 13 science process skills (observing, classifying, inferring, predicting, measuring, recording data, using space-number relationships, defining operationally, hypothesizing, conducting an experiment, determining variables, interpreting data and formulating models) included 40 questions. The test reliability was 0.81 (Cronbach Alpha). In this test, the students got 1 point for each correct answer. The test was worth 40 points in total.

Academic Achievement Tests $\left(6^{\text {th }} \mathbf{G}-\mathbf{A A T}\right.$ and $\left.7^{\text {th }} \mathbf{G}-\mathbf{A A T}\right)$ : The researcher obtained tests from TUBITAK Project number 110K252. The academic achievement test for the sixth grade students $\left(6^{\text {th }} \mathrm{G}-\mathrm{AAT}\right)$ included unit Matter and Heat and the academic achievement test for the seventh grade students $\left(7^{\text {th }}\right.$ G-AAT $)$ included unit "Structure and Features of the Matter". $6^{\text {th }}$ G-AAT and $7^{\text {th }}$ G-AAT comprised 25 multiple choice questions. The tests were evaluated out of 100 points by giving 4 points for each of the questions. According to KR20, the reliability coefficient of these tests was found to be 0.88 for the sixth grade students and 0.75 for the seventh grade students (Doymuş, 2012).

\subsection{Data Analysis}

Shapiro-Wilk analysis was performed to observe whether students' score obtained from were parametric or not, and results of this analysis are given in Table 1.

Table 1. Results of the Shapiro-Wilk Analysis of data obtained from tests

\begin{tabular}{|c|c|c|c|c|c|c|c|}
\hline \multirow[b]{2}{*}{ Tests } & \multicolumn{3}{|c|}{ Shapiro-Wilk } & \multirow[b]{2}{*}{ Tests } & \multicolumn{3}{|c|}{ Shapiro-Wilk } \\
\hline & Statistics & df & p & & Statistics & df & p \\
\hline $6^{\text {th }}$ G-PIT & 0.959 & 46 & 0.104 & $7^{\text {th }} \mathrm{G}$-PIT & 0.986 & 73 & 0.588 \\
\hline $6^{\text {th }}$ G-SPST (posttest) & 0.978 & 46 & 0.510 & $7^{\text {th }} \mathrm{G}_{-S P S T} \mathrm{P}_{\text {(prettest) }}$ & 0.792 & 73 & 0.000 \\
\hline $6^{\text {th }} \mathrm{G}-\mathrm{AAT}$ & 0.974 & 85 & 0.082 & $7^{\text {th }} \mathrm{G}-\mathrm{AAT}$ & 0.977 & 122 & 0.034 \\
\hline $6^{\text {th }}$ G-SPST (posttest) & 0.960 & 85 & 0.010 & $7^{\text {th }} \mathrm{G}_{-S P S T}$ (posttest) & 0.962 & 122 & 0.002 \\
\hline
\end{tabular}


Table 1 showed that $6^{\text {th }}$ G-PIT, $6^{\text {th }}$ G-SPST $\left(\right.$ pretest), $6^{\text {th }}$ G-AAT and $7^{\text {th }}$ G-PIT were parametric while others were nonparametric. According to these results, analyzes were done. This study was used the SPSS package program to analyze quantitative data. The findings obtained from the study tests were analyzed using Independent T-Test and One-Way Factor analysis for parametric data, and MannWhitney $\mathrm{U}$ and Kruskal-Wallis analyzes for nonparametric data.

\section{Findings}

Table 2. Descriptive and predictive statistical results of preliminary information tests $\left(6^{\text {th }} G\right.$-PIT and $\left.7^{\text {th }} G-P I T\right)$ and academic achievement tests $\left(6^{\text {th }} G-A A T\right.$ and $\left.7^{\text {th }} G-A A T\right)$

\begin{tabular}{|c|c|c|c|c|c|c|c|c|c|}
\hline Years & Tests & Groups & $\mathbf{N}$ & $\mathbf{X}$ & SD & df & $\mathbf{t}$ & $\mathbf{p}$ & Difference \\
\hline \multirow{7}{*}{ First Year } & \multirow{2}{*}{$6^{\text {th }} \mathrm{G}-\mathrm{PIT}$} & DG1 & 29 & 52.41 & 15.24 & 45 & 0.499 & 0.621 & \\
\hline & & KG1 & 17 & 50.12 & 14.77 & & & & \\
\hline & Tests & Groups & $\mathbf{N}$ & $\mathbf{X}$ & SD & df & $\mathbf{F}$ & p & \multirow{5}{*}{$\begin{array}{l}\text { EG1>CG1,CG2 } \\
\text { EG2>CG1,CG2 }\end{array}$} \\
\hline & \multirow{4}{*}{$\begin{array}{l}6^{\text {th }} \mathrm{G}- \\
\text { AAT }\end{array}$} & EG1 & 29 & 53.66 & 16.921 & $3-86$ & 12.638 & 0.000 & \\
\hline & & EG2 & 24 & 55.00 & 20.026 & & & & \\
\hline & & CG1 & 17 & 32.47 & 14.345 & & & & \\
\hline & & CG2 & 17 & 31.53 & 11.214 & & & & \\
\hline \multirow{10}{*}{$\begin{array}{l}\text { Second } \\
\text { Year }\end{array}$} & Tests & Groups & $\mathbf{N}$ & $\mathbf{X}$ & SD & df & $\mathbf{F}$ & p & \\
\hline & \multirow{3}{*}{$7^{\text {th }}$ G-PIT } & EG1 & 28 & 41.57 & 13.956 & $2-72$ & 0.683 & 0.509 & \\
\hline & & EG3 & 25 & 41.92 & 12.281 & & & & \\
\hline & & CG1 & 20 & 37.80 & 11.998 & & & & \\
\hline & Tests & Groups & $\mathbf{N}$ & $\mathbf{X}$ & SD & df & $X^{2}$ & $\mathbf{p}$ & \multirow{6}{*}{$\begin{array}{l}\mathrm{EG} 1>\mathrm{EG} 3, \mathrm{CG} 1, \mathrm{CG} 2 \\
\mathrm{EG} 2>\mathrm{EG} 3, \mathrm{CG} 1, \mathrm{CG} 2\end{array}$} \\
\hline & \multirow{5}{*}{$\begin{array}{l}7^{\text {th }} \mathrm{G}- \\
\mathrm{AAT}\end{array}$} & EG1 & 26 & 73.08 & 17.03 & 4 & 31.150 & 0.000 & \\
\hline & & EG2 & 27 & 66.07 & 18.48 & & & & \\
\hline & & EG3 & 27 & 52.00 & 13.59 & & & & \\
\hline & & CG1 & 21 & 45.71 & 21.86 & & & & \\
\hline & & CG2 & 21 & 49.14 & 17.26 & & & & \\
\hline
\end{tabular}

According to results of preliminary information tests in Table 2, it was determined that there was no statistically significant difference between groups in $6^{\text {th }} \mathrm{G}$-PIT and $7^{\text {th }}$ G-PIT $\left[6^{\text {th }}\right.$ G-PIT: $t=0.499$; $p>0.005 .7^{\text {th }}$ G-PIT: $\left.F_{(2-72)}=0.683 ; p>0.05\right]$. It can be stated first and second year that prior science class knowledge of the experimental and control group students before the application were equal. After the applying studies were completed, the students were performed $6^{\text {th }} \mathrm{G}-\mathrm{AAT}$ and $7^{\text {th }} \mathrm{G}-\mathrm{AAT}$, and evaluation results of the obtained data are given in Table 2. The ANOVA analysis results of academic achievement tests $\left(6^{\text {th }} \mathrm{G}-\mathrm{AAT}\right.$ and $\left.7^{\text {th }} \mathrm{G}-\mathrm{AAT}\right)$ in Table II showed that there was a statistically significant difference among groups $\left[6^{\text {th }} \mathrm{G}-\mathrm{AAT}: \mathrm{F}_{(3-86)}=12.638 ; \mathrm{p}<0.05 .7^{\text {th }} \mathrm{G}-\mathrm{AAT}: \mathrm{X}_{(4)}{ }_{(4)}=31.15\right.$; $\mathrm{p}<0.05]$. LSD which is one of the multiple comparison tests was performed to determine if there is a difference between groups in $6^{\text {th }} \mathrm{G}-\mathrm{AAT}$. The LSD analysis was found a statistically significant difference between EG1 and CG1, CG2 and between EG2 and CG1, CG2 ( $\mathrm{p}<0.05)$. It can be concluded that the LT applications made positive contributions to students' success. According to the data obtained from $6^{\text {th }} \mathrm{G}$-AAT, there were no statistically significant differences inter-group comparisons of the experimental (Inter-groups: EG1 and EG2) and control groups (Inter-groups: CG1 and CG2) and there were statistically significant differences according to cross-comparisons. It can be stated that the Solomon research design which had been performed according to the data obtained ensured internal validity and internal reliability of this study. Mann-Whitney $U$ analysis was performed to determine if there is a difference between groups in the form of binary groups in $7^{\text {th }} \mathrm{G}$ AAT. Results of this analysis was found a statistically significant difference between EG1 and EG3, CG1, CG2 and between EG2 and EG3, CG1, CG2 (p<0.05). It can be concluded that the LT applications made positive contributions to students' success. This study was found that students in EG1 and EG2 who had experienced the applications twice got higher scores on $7^{\text {th }}$ G-AAT than those 
in EG3 who had experiences the applying LT only once. According to this result, it can be stated that repetitive applications of LT had positive effects on the children.

Table 3. Descriptive and predictive statistical results of science process skill tests $\left(6^{\text {th }} G\right.$-SPST and $7^{\text {th }} G$-SPST)

\begin{tabular}{|c|c|c|c|c|c|c|c|c|c|}
\hline Years & Tests & Groups & $\mathbf{N}$ & $\mathbf{X}$ & SD & df & $t$ & $\mathbf{p}$ & Difference \\
\hline \multirow{7}{*}{ First Year } & $6^{\text {th }} \mathrm{G}-$ & EG1 & 29 & 15.90 & 5.03 & 45 & 1.959 & 0.056 & \\
\hline & $\mathrm{SPST}_{\text {(pretest) }}$ & CG1 & 17 & 12.88 & 5.05 & & & & \\
\hline & Tests & Groups & $\mathbf{N}$ & $\mathbf{X}$ & SD & df & $\mathrm{X}^{2}$ & $\mathbf{p}$ & \multirow{5}{*}{$\begin{array}{l}\text { EG1 > CG1, CG2 } \\
\text { EG2 > CG1, CG2 }\end{array}$} \\
\hline & \multirow{4}{*}{$\begin{array}{l}6^{\text {th }} \mathrm{G}^{-} \\
\operatorname{SPST}_{\text {(posttest) }}\end{array}$} & EG1 & 29 & 24.04 & 6.386 & 3 & 39.852 & 0.000 & \\
\hline & & EG2 & 24 & 25.87 & 7.653 & & & & \\
\hline & & CG1 & 17 & 14.71 & 5.347 & & & & \\
\hline & & CG2 & 17 & 13.88 & 4.807 & & & & \\
\hline \multirow{9}{*}{$\begin{array}{l}\text { Second } \\
\text { Year }\end{array}$} & Tests & Groups & $\mathbf{N}$ & $\mathbf{X}$ & SD & df & $\mathrm{X}^{2}$ & p & \\
\hline & \multirow{3}{*}{$\begin{array}{l}7^{\text {th }} \mathrm{G}- \\
\operatorname{SPST}_{\text {(pretest) }}\end{array}$} & EG1 & 28 & 20.93 & 6.01 & 2 & 3.766 & 0.152 & \\
\hline & & EG3 & 25 & 21.92 & 6.28 & & & & \\
\hline & & CG1 & 20 & 17.85 & 7.34 & & & & \\
\hline & \multirow{5}{*}{$\begin{array}{l}7^{\text {th }} \mathrm{G}- \\
\operatorname{SPST}_{\text {(posttest) }}\end{array}$} & EG1 & 26 & 27.38 & 5.66 & 4 & 17.399 & 0.002 & \multirow{5}{*}{$\begin{array}{l}\text { EG1>EG3,CG1,CG2 } \\
\text { EG2>EG3,CG1,CG2 } \\
\text { EG3>CG1 }\end{array}$} \\
\hline & & EG2 & 27 & 27.93 & 4.67 & & & & \\
\hline & & EG3 & 27 & 25.24 & 5.28 & & & & \\
\hline & & CG1 & 21 & 21.90 & 6.84 & & & & \\
\hline & & CG2 & 21 & 23.33 & 6.84 & & & & \\
\hline
\end{tabular}

According to results of preliminary information tests in Table 3, it was determined that there was no statistically significant difference between groups in $6^{\text {th }} \mathrm{G}-\mathrm{SPST} \mathrm{T}_{\text {(pretest) }}$ and $7^{\text {th }} \mathrm{G}-\mathrm{SPST}_{\text {(pretest) }}\left[6^{\text {th }} \mathrm{G}-\right.$ $\left.\operatorname{SPST}_{(\text {pretest) }}: t=1.959 ; p>0.005 .7^{\text {th }} G-S P S T: X_{(2)}^{2}=3.766 ; p>0.05\right]$. It can be stated first and second that science process skills levels of the experimental and control group students before the application were equal. After the applying studies were completed, the students were performed $6^{\text {th }} \mathrm{G}-\mathrm{SPST}_{\text {(posttest) }}$ and $7^{\text {th }} \mathrm{G}_{-} \mathrm{SPST}_{\text {(posttest), }}$, and evaluation results of the obtained data are given in Table III. The KruskalWallis analysis in Table-3 determined that there were statistically significant differences among groups in $6^{\text {th }} \mathrm{G}-\mathrm{SPST}_{\text {(posttest) }}\left[\mathrm{X}_{(3)}{ }_{(3)}=39.852 ; \mathrm{p}<0.05\right]$. To determine which group was more successful, this study performed a Mann-Whitney $U$ analysis in the form of binary groups. According to this analysis was determined a statistically significant difference between EG1 and CG1, CG2 and between EG2 and CG1, CG2 (p<0.05). According to the data obtained from $6^{\text {th }} \mathrm{G}-\mathrm{SPST}_{\text {(posttest), there were no }}$ statistically significant differences inter-group comparisons of the experimental (Inter-groups: EG1 and EG2) and control groups (Inter-groups: CG1 and CG2) and there were statistically significant differences according to cross-comparisons. It can be concluded that the LT applications made positive contributions to students' science process skills. It can be stated that the Solomon research design which had been performed according to the data obtained ensured internal validity and internal reliability of this study.

Kruskal-Wallis analysis was performed to determine if there is a difference between groups for each science process skill (Table 4).

Table 4. Descriptive and predictive statistical results of $6^{\text {th }} G-S P S T_{\text {(posttest) }}$ for each skill in the application first

\begin{tabular}{|l|l|r|r|r|r|r|l|}
\hline Science Process Skills & Groups & $\mathbf{N}$ & Mean Rank & $\mathbf{d f}$ & $\mathbf{X}^{\mathbf{2}}$ & $\mathbf{p}$ & Difference \\
\hline \multirow{5}{*}{ Logical Thinking } & EG1 & 29 & 54.46 & 3 & 30.385 & $\mathbf{0 . 0 0 0}$ & EG1 > CG1, CG2 \\
& EG2 & 24 & 55.52 & & & & EG2 > CG1, CG2 \\
\cline { 2 - 8 } & CG1 & 17 & 23.97 & & & & \\
& CG2 & 17 & 26.21 & & & & \\
\hline \multirow{5}{*}{ Predicting } & EG1 & 29 & 55.25 & 3 & 19.571 & $\mathbf{0 . 0 0 0}$ & DG1 > CG1, EG2 \\
& EG2 & 24 & 42.63 & & & & \\
\cline { 2 - 7 } & CG1 & 17 & 22.76 & & & & \\
\cline { 2 - 5 } & CG2 & 17 & 43.56 & & & & \\
\hline
\end{tabular}




\begin{tabular}{|c|c|c|c|c|c|c|c|}
\hline \multirow[t]{4}{*}{ Questioning } & EG1 & 29 & 54.55 & 3 & 24.577 & 0.000 & \multirow{4}{*}{$\begin{array}{l}\mathrm{EG} 1>\mathrm{CG} 1, \mathrm{CG} 2 \\
\mathrm{EG} 2>\mathrm{CG} 1, \mathrm{CG} 2\end{array}$} \\
\hline & EG2 & 24 & 51.72 & & & & \\
\hline & CG1 & 17 & 23.32 & & & & \\
\hline & CG2 & 17 & 31.85 & & & & \\
\hline \multirow[t]{4}{*}{ Researching } & EG1 & 29 & 52.21 & 3 & 20.902 & 0.000 & \multirow{4}{*}{$\begin{array}{l}\mathrm{EG} 1>\mathrm{CG} 1, \mathrm{CG} 2 \\
\mathrm{EG} 2>\mathrm{CG} 1, \mathrm{CG} 2\end{array}$} \\
\hline & EG2 & 24 & 53.74 & & & & \\
\hline & CG1 & 17 & 28.79 & & & & \\
\hline & CG2 & 17 & 27.50 & & & & \\
\hline \multirow[t]{4}{*}{ Communicating } & EG1 & 29 & 43.00 & 3 & 26.339 & 0.000 & \multirow{4}{*}{$\begin{array}{l}\mathrm{CG} 2<\mathrm{EG} 1, \mathrm{CG} 1 \\
\mathrm{EG} 2>\mathrm{EG} 1, \mathrm{CG} 1, \mathrm{CG} 2\end{array}$} \\
\hline & EG2 & 24 & 61.67 & & & & \\
\hline & CG1 & 17 & 37.68 & & & & \\
\hline & CG2 & 17 & 23.06 & & & & \\
\hline \multirow[t]{4}{*}{ Planning and Producing } & EG1 & 29 & 50.52 & 3 & 31.713 & 0.000 & \multirow{4}{*}{$\begin{array}{l}\mathrm{EG} 1>\mathrm{CG} 1, \mathrm{CG} 2 \\
\mathrm{EG} 2>\mathrm{CG} 1, \mathrm{CG} 2\end{array}$} \\
\hline & EG2 & 24 & 59.91 & & & & \\
\hline & CG1 & 17 & 24.97 & & & & \\
\hline & CG2 & 17 & 25.76 & & & & \\
\hline
\end{tabular}

According to the Kruskal-Wallis analysis in Table 4, this study showed that there was a statistically significant difference among groups according to each science process skill of $6^{\text {th }} \mathrm{G}$-SPST $[$ Logical Thinking: $X_{(3)}^{2}=30.385 ; p<0.05$. Predicting: $X_{(3)}^{2}=19.571 ; p<0.05$. Questioning: $X_{(3)}^{2}=24.577 ; p<0.05$. Researching: $X_{(3)}^{2}=20.902 ; p<0.05$. Communicating: $X_{(3)}^{2}=26.339 ; p<0.05$. Planning and Producing: $\mathrm{X}_{(3)}^{2}=31.713$; $\left.\mathrm{p}<0.05\right]$. Mann-Whitney $\mathrm{U}$ analysis was performed to determine if there is a difference between groups in the form of binary groups. This study showed that the scores of EG1 and EG2 on the test for "Logical Thinking", "Questioning", "Researching" and "Planning and Producing" skills were higher than the scores of CG1 and CG2 and were statistically significant $(p<0.05)$. According to these results, it can be said that the LT applications had a positive effect on students' science process skills.

The Kruskal-Wallis analysis in Table 4 found a statistically significant difference between groups in $7^{\text {th }} \mathrm{G}^{-\mathrm{SPST}_{\text {(posttest) }}}\left[\mathrm{X}_{(3)}^{2}=39.852 ; \mathrm{p}<0.05\right]$. Mann-Whitney $\mathrm{U}$ analysis was performed to determine if there is a difference between groups in the form of binary groups. According to the results of this analysis, it was found that there was a statistically significant difference between EG1 and EG3, CG1, CG2 and between EG2 and EG3, CG1, CG2 and also between EG3 and CG1 (p<0.05). A statistically significant difference between experimental groups, to which the LT applications were performed twice, and an experimental group, to which applications were performed only once, showed that applying LT twice made positive contributions to students' science process skills.

Kruskal-Wallis analysis was performed to determine if there is a difference between groups for each science process skill (Table 5).

Table 5. Descriptive and predictive statistical results of $7^{\text {th }} \mathrm{G}-\mathrm{SPST}_{\text {(Posttest) }}$ according to each skill in the application second

\begin{tabular}{|l|l|l|r|r|r|r|l|}
\hline Science Process Skills & Groups & $\mathbf{N}$ & $\begin{array}{r}\text { Mean } \\
\text { Rank }\end{array}$ & sd & $\mathbf{X}^{2}$ & $\mathbf{p}$ & Difference \\
\hline \multirow{4}{*}{ Measuring } & EG1 & 26 & 77.27 & 4 & 13.440 & $\mathbf{0 . 0 0 9}$ & \multirow{2}{*}{ EG1 > EG3, CG1, CG2 } \\
& EG2 & 27 & 71.06 & & & & \multirow{2}{*}{ EG2 > EG3, CG2 } \\
\hline & EG3 & 27 & 50.41 & & & & \\
\hline & CG1 & 21 & 55.45 & & & & \\
\hline & CG2 & 21 & 50.00 & & & & \\
\hline \multirow{5}{*}{ Recording Data } & EG1 & 26 & 59.71 & 4 & 9.811 & $\mathbf{0 . 0 4 4}$ & EG2 > EG1, CG1, CG2 \\
& EG2 & 27 & 72.81 & & & & \multirow{2}{*}{ EG3 > CG2 } \\
\hline & EG3 & 27 & 64.83 & & & & \\
& CG1 & 21 & 62.88 & & & & \\
& CG2 & 21 & 43.50 & & & & \\
\hline
\end{tabular}




\begin{tabular}{|c|c|c|c|c|c|c|c|}
\hline \multirow[t]{5}{*}{ Hypothesizing } & EG1 & 26 & 71.87 & 4 & 15.051 & 0.005 & \multirow{5}{*}{$\begin{array}{l}\mathrm{EG} 1>\mathrm{EG} 3, \mathrm{CG} 1, \mathrm{CG} 2 \\
\mathrm{EG} 2>\mathrm{EG} 3, \mathrm{CG} 1, \mathrm{CG} 2\end{array}$} \\
\hline & EG2 & 27 & 76.54 & & & & \\
\hline & EG3 & 27 & 50.48 & & & & \\
\hline & CG1 & 21 & 49.17 & & & & \\
\hline & CG2 & 21 & 55.83 & & & & \\
\hline \multirow[t]{5}{*}{ Conducting an Experiment } & EG1 & 26 & 71.85 & 4 & 13.248 & 0.010 & \multirow{5}{*}{$\begin{array}{l}\text { EG1 > CG1, CG2 } \\
\mathrm{EG} 2>\mathrm{EG} 3, \mathrm{CG} 1, \mathrm{CG} 2\end{array}$} \\
\hline & EG2 & 27 & 76.19 & & & & \\
\hline & EG3 & 27 & 54.98 & & & & \\
\hline & CG1 & 21 & 49.17 & & & & \\
\hline & CG2 & 21 & 50.52 & & & & \\
\hline \multirow[t]{5}{*}{ Determining Variables } & EG1 & 26 & 75.81 & 4 & 15.695 & 0.003 & \multirow{5}{*}{$\begin{array}{l}\mathrm{EG} 1>\mathrm{EG} 3, \mathrm{CG} 2 \\
\mathrm{EG} 2>\mathrm{EG} 3, \mathrm{CG} 2\end{array}$} \\
\hline & EG2 & 27 & 73.35 & & & & \\
\hline & EG3 & 27 & 51.17 & & & & \\
\hline & CG1 & 21 & 59.26 & & & & \\
\hline & CG2 & 21 & 44.07 & & & & \\
\hline
\end{tabular}

According to the Kruskal-Wallis analysis in Table 5, there was a statistically significant difference among groups in the science process skills of $7^{\text {th }}$ G-SPST such as "Measuring", "Recording Data", "Hypothesizing", "Conducting an Experiment" and "Determining Variables" $(p<0.005)$. It can be concluded that the LT method made positive contributions to students' success. Mann-Whitney U analysis was performed to determine if there is a difference between groups in the form of binary groups. Statistically significant differences are given in Table V. These results were indicated that the experimental groups, to which the application was performed twice, were better than both of the control groups and the other experimental group, to which the application was performed only once, with skills of "measuring", "hypothesizing", "conducting an experiment" and "determining variables". It can be stated that the LT applications enabled students to improve these skills.

Moreover, a two-factor design was obtained to determine the size of the effect (ETA square) of LT in posttests by forming one experimental group combining all of the experimental groups (EG1 and EG2) in the study and one control group (CG) combining all of the control groups (CG1 and CG2) in the study (Karasar, 2016). The ETA square results obtained from this study design are given in Table 6.

Table 6. The effect size (ETA square)

\begin{tabular}{|l|r|r|}
\hline \multirow{2}{*}{ Groups } & \multicolumn{2}{|c|}{ ETA square } \\
\cline { 2 - 3 } & ${\mathbf{7}^{\text {th }} \mathbf{G - A A T}}^{\text {th }}$-SPST (posttest) \\
\hline EG (EG1+EG2) and CG (CG1+CG2) & 0,261 & 0,156 \\
\hline EG (EG1+EG2) and EG3 & 0,203 & 0,076 \\
\hline EG3 and CG (CG1+CG2) & 0,037 & 0,032 \\
\hline
\end{tabular}

According to the ETA square values in Table VI, it was determined that $26 \%$ of the mean scores between EG and CG for academic success and 16\% of mean scores for the science process skills, and $20 \%$ of the mean scores between EG and EG3 for academic success and 8\% of the mean scores for science process skills, and $4 \%$ of the mean scores of EG3 and CG for academic success and 3\% of the mean scores for science process skills were explained by the applying LT with the study research design. According to these results, it can be said that the effect of applying LT twice on changes in scores of academic success and science process skills were higher than other situations.

\section{Conclusions and Discussion}

By application LT Method two times at different intervals, academic success of middle school students in science and its impact on improvement of their science process skills were explored. The model and methods to be selected for active learning are closely related to the research design applied. This study was examined the efficiency of applying the learning together method with the Solomon 
experimental design in science class on middle school sixth and seventh students' academic success and improvement of their science process skills.

The data which were obtained from the pretests $\left(6^{\text {th }}\right.$ G-PIT, $7^{\text {th }}$ G-PIT, $6^{\text {th }}$ G-SPST, and $7^{\text {th }}$ G-SPST) performed before the applications were showed that there was no statistically significant difference among the groups. According to these results, it can be argued that science process skills and prior science class knowledge of the study groups before the application were equal.

The results of the pretest and posttest were indicated that there were no statistically significant differences between the groups according to inter-group comparison, but statistically significant differences were found according to cross-group comparison. These results showed that the effects of the pretest applications were minimized. In the literature, pretest applications have had some effects on students such as psychological sensitizing, creating an environment of competition and unexpected learning (Babbie, 2013; Sawilowsky, Kelley, Blair, and Markman, 1994). These effects cause deviations in the study results. The Solomon research design increased the validity of the interpretations of the application's efficiency by eliminating these effects (Karasar, 2016). The application is performed by using Solomon Research Design for findings to provide internal and external validity of research and the effectiveness of LT Method is tried to be fully revealed.

According to the data collected from $6^{\text {th }} \mathrm{G}$-AAT and $6^{\text {th }} \mathrm{G}$-SPST after applying the LT once, a significant difference was found in favor of the experimental groups (EG1, EG2). These results can be argued that the LT method positively made a contribution to students' academic success and science process skills in unit "Matter and Heat". The results of studies conducted using LT support the findings of this study (Aksoy, 2011; Aksoy and Doymuş, 2012; Arreguin-Anderson and Esquierdo, 2011; Bilgin and Geban, 2006; Çetin, 2015; Gambari, Yusuf, and Thomas, 2015; Gök, Doğan, Doymuş, and Karaçöp, 2009; Johnson, Sadeck, and Hodges, 2002; Orprayoon, 2014; Zorlu, 2016; Zorlu and Sezek, 2016). This study was found a significant difference in favor of the experimental groups on "Logical Thinking", "Predicting", "Questioning", "Researching", "Communicating" and "Planning and Producing" skills of science process skills. To achieve success in the LT application, it is required that group members plan their studies together. Thus, they can present a common outcome by thinking together to learn (Nixon, 2015; Woods-McConney, Wosnita, and Strucrock, 2016). In this process, members can also encounter some problems. To find solutions for these problems, they can make predictions using reasoning methods. The fact that the experimental group participants gained more science process skills in the first application of LT is a sign of the effectiveness of acquiring these skills.

According to the data collected from $7^{\text {th }} \mathrm{G}-\mathrm{AAT}$ and $7^{\text {th }} \mathrm{G}-\mathrm{SPST}$ after applying the LT method twice, more statistically apparent significant differences were found in favor of the experimental groups. This study was also determined that the experimental groups to whom the application was applied twice had statistically improved academic success of "Structure and Properties of Matter" unit and science process skills over the experimental group to whom the application was applied only once. According to these findings, it can be stated that applying the Solomon research design and the LT method twice at different times can improve students' academic success and science process skills. Students in heterogeneous groups study together, and they research the lesson to be taught before class; these are the basic characteristics of LT. Students study together in a group and learn the subject, getting ahead by knowing the applied method (Kaufman, 2014; Schwarz, de Groot, Mavrikis, and Dragon, 2015). Thus, they can make up the deficiency during the lesson by working together and supporting one another. A study of Johnson, Johnson and Holubec (1994) indicated that students support each other by working together in cooperative learning, and thus, they jointly achieved better success than they achieve individually. Moreover, according to the results of $7^{\text {th }}$ G-SPST, students' "Measuring", "Hypothesizing", "Conducting an Experiment" and "Determining Variables" skills improved more than other skills. These skills are among the science process skills which mostly take place in acquisitions of unit "Structure and Features of the Matter" (MEB, 2013). It can be stated that both applications performed at different times assisted students in improving their science process skills of the unit by enabling them to use the process more efficiently and effectively because they had learned the method. 
It was determined that the effect size of eta squared values big effect size between "applying LT twice" and "using the existing learning method". If eta square value is greater than 0.14 , it means big effect size (Pallant, 2006; p. 201). It was determined that listing the effect size of eta squared values, which was obtained to determine the contributions of LT to students' academic success and science process skills, from more to less was as follows: "applying LT twice", "applying LT once" and "using the existing learning method". Thus, it can be argued that the scores obtained from the tests were consistent and that applications which were applied to the same sample more than once using the Solomon experimental design increased the reliability of this study. Furthermore, this study was obtained three different groups (two experimental groups which were performed the applications to twice, an experimental group which was performed the applications to once, and one control group) to compare by performing the applications to twice. This allowed a vertical comparison of the effects, which will be created by a method in terms of application time or frequency, on its own merits. In the literature, there is no study that an active learning method had been applied twice to the same sample within two years by using the Solomon experimental design.

It can be argued that applying LT twice to the same sample within two years by using the Solomon experimental design has increased the relationship between the independent and dependent variables. This has increased the ability to explain the fact that changes in the independent variable lead to changes in the dependent variables using the same participants by providing justification. This study determined a more powerful relationship between cause and effect variables as the application time or frequency increased. Furthermore, it can be stated that the results of this application performed using the Solomon research design increased the ability to generalize the application with other people (population validity), environments (ecological validity), experiments (experiment validity) and times (time validity) (Christensen, Johnson, and Turner, 2015). Considering the above-mentioned reasons, performing an application twice within two years using the Solomon experimental design increased the external validity of this study.

Children like applied science; it is interesting to have problem to solve, make a research and discover something new. They could obtain more fruitful sharing with studies they performed by mutually interacting with their peers in LT. Determining the methods that provides these experiences enables the students to shape their perspective to learn science and offer many advantages. Thus it is of capital importance for science educators and teachers. In further studies, applying the cooperative learning model with the Solomon research design more than once at different times and also comparing two additional experimental groups (with pretest and without pretest) which will be included in the design in every application can enable researchers to obtain more effective results in terms of study objectives. The effectiveness of the different learning methods can be measured better by using this experimental design.

\section{References}

Açıkgöz, K. Ü. (1992). The cooperative learning: Theory, research and application, Malatya: Uğurel.

Aksoy, G. (2011). Effects of reading-writing-application and learning together methods on student's understanding of laboratory experiments in science and technology course, Unpublished doctorate' thesis, Ataturk University, Erzurum, Turkey.

Aksoy, G., \& Doymuş, K. (2012). The effects of different cooperative techniques on prospective science teachers' laboratory achievement in general chemistry course, Bayburt University Journal of Education, 7(1), 30-40.

Apugliese, A., \& Lewis, S. E. (2017). Impact of instructional decisions on the effectiveness of cooperative learning in chemistry through meta-analysis, Chemistry Education Research and Practice, 18(1), 271-278.

Arreguin-Anderson, M. G., \& Esquierdo, J. J. (2011). Overcoming difficulties, Science and Children, 48(7), 68-71.

Avc1, S. (2002). Active learning, Retrieved August 10, 2015 from http://www.Mlokurs.Virtuale.Net. 
Babbie, E. (2013). The basis of social research (16th ed.). Belmont, USA: Wadsworth Cengage Learning.

Bayrakçeken, S., Doymuş, K., \& Doğan, A. (2013). Applying the cooperative learning, Ankara: Pegem.

Bilgin, I., \& Geban, O. (2006). The effect of cooperative learning approach based on conceptual change condition on students' understanding of chemical equilibrium concepts, Journal of Science Education and Technology, 15(1), 31-46. doi:10.1007/s10956-006-0354-z

Bozdoğan, A. E., Taşdemir, A., \& Demirbaş, M. (2006). The effect of cooperative learning method in science education on improving the students' science process skills, Inönü University Journal of Education, 7(11), 23-36.

Cardoso, M. L., Branco, C., \& Solomon, J. (2002). Studies of Portuguese and British primary pupils learning science through simple activities in the home, International Journal of Science Education, 24(1), 47-60. doi: 10.1080/09500690110049079

Christensen, L. B., Johnson, R. B., \& Turner, L. A. (2015). Research methods: Design and analysis, (Trans. A. Alpay). Ankara: An1.

Çetin, A. (2015). The effects of physics experiments designed by cooperative learning on pre-service teachers' science process skills and physics attitudes, Siirt University Journal of Social Sciences Institute, 4, 1-12.

Daşdemir, İ., \& Doymuş, K. (2012).The effect of using animation on primary science and technology course students' academic achievement, retention of knowledge and scientific process skills, Pegem Journal of Education and Instruction, 2(3), 33-42.

Doymuş, K. (2008). Teaching chemical bonding through jigsaw cooperative learning, Research in Science \& Technological Education, 26(1), 47-57. doi: 10.1080/02635140701847470

Doymuş, K. (2012). Informing of science and technology teachers applications of cooperative learning model, in the class and evaluating the obtained results (110K252). The TUBITAK Project.

Doymuş, K., \& Koç, Y. (2012). Application in the classroom of cooperative learning model of science and technology teachers, Dicle University Journal of Ziya Gökalp Faculty of Education, 19, 174-183.

Ebrahim, A. (2012). The effect of cooperative learning strategies on elementary students' science achievement and social skills in Kuwait, International Journal of Science and Mathematics Education, 10(2), 293-314. doi:10.1007/s10763-011-9293-0

Ergin, Ö., Şahin-Pekmez, E., \& Öngel-Erdal, S. (2005). Teaching science through experimentation from theory to practice, İzmir: Dinazor.

Gambari, A. I., Yusuf, M. O., \& Thomas, D. A. (2015). Effects of computer-assisted STAD, LTM and ICI cooperative learning strategies on Nigerian secondary school students' achievement, gender and motivation in physics, Malaysian Online Journal of Educational Sciences, 3(4), 11-26. Retrieved from http://www.moj-es.net/volume/volume-03-issue-04

Gök, Ö., Doğan, A., Doymuş, K., \& Karaçöp, A. (2009). The effects of cooperative learning on elementary school students' academic achievement and attitudes toward science, Gazi University Journal of Gazi Educational Faculty, 29(1), 193-209.

Johnson, R. T., \& Johnson, D. W. (1986). Cooperative learning in the science classroom, Science and Children, 24, 31-32.

Johnson, D. W., \& Johnson, R. T. (1996). Cooperation and the use of technology. Handbook of research for educational communications and technology: A project of the Association for Educational Communications and Technology, 1017-1044.

Johnson, D. W., \& Johnson, R. T. (1999). Making cooperative learning work, Theory into Practice, $38(2), 67-73$. 
Johnson, R.T., Johnson, D. W., \& Holubec, E. J. (1994). New circles of learning: cooperation in the classroom and school, Alexandra, VA, USA: Association for Supervision \& Curriculum Development (ASCD).

Johnson, S., Sadeck, M., \& Hodges, M. (2002). Developing science process skills in special schools in South Africa, Journal of Research in Special Educational Needs, 2(1), 1-8. Doi: 10.1111/j.14713802.2002.00159.x

Karakoyun, M. E. (2010). The effect of one of the collaborative learning techniques, Jigsaw I, to academic success in the teaching of punctuation to elementary education 5th grade students, Unpublished masters' thesis, Ataturk University, Erzurum, Turkey.

Karasar, N. (2014). Scientific research method, Ankara: Nobel.

Kaufman, S. (2014). Learning together. Schools: Studies in Education, 11(2), 263-305. doi: $10.1086 / 678219$

Köseoğlu, F., \& Kavak, N. (2001). Constructivist approach in science teaching, Gazi University Journal of Gazi Educational Faculty, 21(1), 139-148.

Mei, Y. T. G. Kaling, C., Xinyi, C. S., Sing, J. S. K., \& Khoon, K. N. S. (2007). Promoting science process skills and the relevance of science through science alive programme. In Proceedings of Redesigning Pedagogy: Culture, Knowladge and Understanding Conference, Singapore, Environmental \& Science Education, 3(1), 30-34.

Nixon, J. (2015). Learning to think together. Teaching in Higher Education, 20(4), 362-372. doi: $10.1080 / 13562517.2015 .1022057$

Orprayoon, S. (2014). Effects of cooperative learning on learning achievement and group working behavior of junior students in modern French literature course, Journal of Effective Teaching, 14(1), 80-98.

Pallant, J. (2006). SPSS survival manual (2nd ed.), Berkshire: Open University Press

Sanc1, M., \& Kılıç, D. (2011).The effects of jigsaw and group study technıques on students' academic achievement in the primary education fourth grade science and technology course, Journal of Educational and Instructional Studies in The World, 1(1), 80-92.

Sawilowsky, S., D. Kelley, L., R. Blair, C., \& Markman, B. S. (1994). Meta-analysis and the solomon four-group design, The Journal of Experimental Education, 62(4), 361-376. doi: 10.1080/00220973.1994.9944140

Schwarz, B. B., de Groot, R., Mavrikis, M., \& Dragon, T. (2015).Learning to learn together with CSCL tools, International Journal of Computer-Supported Collaborative Learning, 10(3), 239-271. doi: 10.1007/s11412-015-9216-0

Sharan, Y. (2015). Meaningful learning in the cooperative classroom, International Journal of Primary, Elementary and Early Years Education 3-13, 43(1), 83-94. doi: 10.1080/03004279.2015.961723

Slavin, R. (2013). Cooperative learning and achievement: Theory and research In Handbook of Psychology, edited by W. Reynolds, G. Miller, and I. Weiner, 7(2), 199-212. Hoboken, NJ: Wiley.

Solomon, R. L. (1949). An extension of control group design, Psychological Bulletin, 46(2), 137-150. doi: $10.1037 / \mathrm{h} 0062958$

Solomon, R. L., \& Lessac, M. S. (1968). A control group design for experimental studies of $\begin{array}{lllll}\text { developmental processes, } & \text { Psychological Bulletin, } & \text { 70(31), 145-150. }\end{array}$ http://dx.doi.org/10.1037/h0026147

Wheeler, R., \& Ryan, F. L. (1973). Effects of cooperative and competitive classroom environments on the attitudes and achievement of elementary school students engaged in social studies inquiry activities, Journal of Educational Psychology, 65(3), 402. 
Woods-McConney, A., Wosnita, M., \& Strucrock, K. L. (2016). Inquiry and groups: student interactions in cooperative inquiry-based science, International Journal of Science Education, 38(5), 842-860. doi:10.1080/09500690802713507

Zorlu, Y. (2016). Effects of activities based on modeling learning method and cooperative learning model of students in elementary science and technology course, Unpublished doctorate' thesis, Ataturk University, Erzurum, Turkey.

Zorlu, Y., \& Sezek, F. (2016). The investigation of effects to learning together method with modeling based learning method on constructivist learning environment. Journal of EKEV Academy, 20(68), 415-430.

Zorlu, F., Zorlu, Y., Sezek, F., \& Akkuş, H. (2014). Secondary eighth graders' the scores of scientific process skills and their relationship with the scores of theirs placement test results. Journal of EKEV Academy, 59(59), 519-532.

\section{Authors}

Fulya ZORLU, Zonguldak Bülent Ecevit University, Faculty of Ereğli Education, Department of Primary Science Education, Zonguldak, Turkey, e-mail: fulya.zorlu@beun.edu.tr

Fatih SEZEK, Atatürk University, Faculty of Kazım Karabekir Education, Department of Primary Science Education, Erzurum, Turkey, e-mail: fsezek@gmail.com

\section{Acknowledgement}

This study is derived from the doctoral dissertation titled "Investigation of effectiveness of application of Solomon research design to cooperative learning model in teaching science lesson" written by Fulya ZORLU. 